\title{
FOOD LOSS DRIVERS IN THE UPSTREAM FOOD SUPPLY CHAIN: A SYSTEMATIC LITERATURE REVIEW*
} Ebru SÜRÜCÜ BALCI ${ }^{1}$, Okan TUNA ${ }^{2}$

\begin{abstract}
Food loss is one of the factors that lead to severe problems in food security, environment, global and regional and national economies around the world today. The issue of food loss reduction has recently achieved much public attention to combat global hunger and improve food security. There is a growing trend about determining food loss prevention and recovery programs all around the world. Similarly, the number of studies that focus on food loss issues has been increased but these studies mostly give attention to consumer/household stages. Thus, this paper aims to gather and synthesize all food loss drivers that are found in empirical studies. For this purpose, a systematic literature review was conducted. We examined articles from different journals, which are published between 2011 and 2018. Results of the systematic literature review revealed that four drivers cause food loss in the production stage; five drivers lead to food loss in the processing stage and five drivers are the reason for food loss in the distribution and retailing stage.
\end{abstract}

Key Words: Food Loss, Food Loss Drivers, Food Supply Chain, Systematic Literature Review

JEL Classification: L66, Q18, R49

\section{GIDA TEDARİK ZİNCİRINDE GIDA İSRAFININ GEREKÇELERİ: SISTEMATIK LITERATÜR TARAMASI}

\section{Öz}

Gıda kaybı günümüzde gıda güvenliği, çevre, küresel ve bölgesel ve ulusal ekonomilerde ciddi sorunlara yol açan faktörlerden biridir. Gıda kaybının azaltılması konusu son zamanlarda küresel açlıkla mücadele etmek ve gıda güvenliğini artırmak için halkın dikkatini çekti. Tüm dünyada gıda kaybı önleme ve geri kazanım programlarının belirlenmesi konusunda giderek artan bir eğilim söz konusudur. Benzer şekilde, gıda kaybı sorunlarına odaklanan çalışmaların sayısı artırılmıştır, ancak bu çalışmalar çoğunlukla tüketici / hanehalkı aşamalarına dikkat çekmektedir. Bu nedenle, bu çalışma ampirik çalışmalarda bulunan tüm gıda kaybı sürücülerini toplamayı ve sentezlemeyi amaçlamaktadır. Bu amaçla sistematik bir literatür taraması yapıldı. 2011-2018 yılları arasında yayınlanan farklı dergilerden makaleleri inceledik. Sistematik literatür taramasının sonuçları, dört sürücünün üretim aşamasında gıda kaybına neden olduğunu; beş sürücü işleme aşamasında gıda kaybına, beş sürücü dağıtım ve perakende aşamasında gıda kaybına neden olmaktadır.

Anahtar Kelimeler: Gıda israfı, Gıda israfı nedenleri, Gıda tedarik zinciri, Sistematik Literatür Taramas1

JEL Sinıflaması: L66, Q18, R49

\footnotetext{
*This paper is based on a part of the unpublished doctoral dissertation.

${ }^{1}$ Research Asst., Manisa Celal Bayar University, Faculty of Business, ebru.surucu@ @ cbu.edu.tr, ORCID: 0000-0002-1224-944X

${ }^{2}$ Prof. Dr., Dokuz Eylul University, Maritime Faculty, otuna@deu.edu.tr, ORCID ID: 0000-0001-84343753
} 


\section{Introduction}

Food loss (FL) has become a prominent issue all over the world. Each year, 1.6 billion tons of food, worth approximately $\$ 1.2$ trillion, is wasted. This amount of wastage represents approximately a third of all food produced, while 821 million of the world's 7.6 billion people suffered from chronic undernourishment in 2017 (FAO, 2018). However, while food becomes waste not only the food itself turn into wastage, but the resources (water, energy, seeds, labor) used to produce that food also turns into wastage. Moreover, a recently published study suggested that overall food production should be increased by anywhere from $25-70 \%$ between now and 2050 (Huston, 2017). From this snapshot, food loss can be considered as one of the significant threat while reaching a sustainable future

FL also affects the environment, economy and society (Halloran et al., 2014; Gjerris and Gaiani, 2013; Buzby and Hyman, 2012). Economically, FL is a sunk investment that reduces farmers' incomes and increases expenses (Lipinski et al., 2013). Moreover, decreasing FL increases the efficiency of food supply chains (Parfitt et al., 2010), which makes foods available to consumers and ultimately decreases food prices and household expenses (Gustavsson et al., 2011). Environmentally, approximately 8 percent of annual greenhouse gas emission comes from FL, meaning that if it were a country, FL would be the third biggest emitter after the USA and China (Hanson and Mitchell, 2017). Besides, wasted food is usually discarded in landfills, where it emits methane, which is 25 times more hazardous to the ozone layer than the $\mathrm{CO}_{2}$ (Gunders, 2012). Also, FL implies that scarce natural resources are being used inefficiently (Hodges et al., 2011). For instance, Kummu et al. (2012) calculated that FL causes a loss of 23-24\% of the water, farmland, and fertilizers used for food production. Socially, the lost and wasted food could have been used to fight hunger, poverty, and malnutrition (von Grebmer et al., 2016; Loopstra et al., 2015; Parfitt et al., 2010). In short, considering the economic, environmental, and social consequences, decreasing FL can play a crucial role in ensuring food security for the world's projected population of 9 billion people by 2050 .

Studies revealed that waste occurs in each stage of the food supply chain (FSC) (Göbel et al., 2015; Kummu et al., 2012). The main distinctive characteristics of FL) and food waste (FW) is at what stage of the supply chain the waste occurs. However, there are no agreed definitions of "food loss" and "food waste" in the literature because of different research questions, data sources, methodologies, and cultures studied. (Busetti, 2019; Teuber and Jensen, 2016; Gjerris and Gaiani, 2013). Priefer et al. (2013) ascertained that the preferred usage sets the limits of the study. Table 1 shows the commonly used food loss and food waste definitions. 
Table 1. The most commonly used food loss and food waste definitions

\begin{tabular}{|c|c|c|c|}
\hline $\begin{array}{l}\text { Food Waste } \\
\text { Source }\end{array}$ & Definition & $\begin{array}{l}\text { Food Loss } \\
\text { Source }\end{array}$ & Definition \\
\hline FAO, 1981 & $\begin{array}{l}\text { All food products allocated for } \\
\text { human consumption that are instead } \\
\text { discarded, lost, degraded, or } \\
\text { consumed by pests at any stage of } \\
\text { the food chain }\end{array}$ & FAO, 1981 & $\begin{array}{l}\text { Wholesome edible material intended for } \\
\text { human consumption arising at any point } \\
\text { in the FSC that is instead discarded, } \\
\text { lost, degraded or consumed by pets }\end{array}$ \\
\hline $\begin{array}{l}\text { Gustavsson et } \\
\text { al., } 2011\end{array}$ & $\begin{array}{l}\text { Part of food loss: it commonly } \\
\text { occurs in developed economics at } \\
\text { both the retail and consumer end, as } \\
\text { a result of either poor planning or } \\
\text { business decisions, as well as lack of } \\
\text { technological infrastructure, } \\
\text { capabilities or consumer awareness }\end{array}$ & $\begin{array}{l}\text { Gustavsson } \\
\text { et al., } 2011\end{array}$ & $\begin{array}{l}\text { The decrease in edible food mass } \\
\text { throughout the part of the supply chain } \\
\text { that specifically leads to edible food for } \\
\text { human consumption }\end{array}$ \\
\hline $\begin{array}{l}\text { Lipinski et al., } \\
2013\end{array}$ & $\begin{array}{l}\text { Food that is of good quality and fit } \\
\text { for human consumption but that does } \\
\text { not get consumed because it is } \\
\text { discarded - either before or after it } \\
\text { spoils }\end{array}$ & $\begin{array}{l}\text { Lipinski et } \\
\text { al., } 2013\end{array}$ & $\begin{array}{l}\text { Spills, spoils, incurs an abnormal } \\
\text { reduction in quality such as bruising or } \\
\text { wilting, or otherwise gets lost before it } \\
\text { reaches the consumer }\end{array}$ \\
\hline FAO, 2013 & $\begin{array}{l}\text { Food appropriate for human } \\
\text { consumption that is discarded } \\
\text { (generally at retail and consumption } \\
\text { stages) }\end{array}$ & FAO, 2013 & $\begin{array}{l}\text { A decrease in mass or nutritional value } \\
\text { of food originally intended for human } \\
\text { consumption, usually caused by } \\
\text { inefficiencies in the FSC (poor } \\
\text { infrastructures and logistics, lack of } \\
\text { technology, insufficient skills, } \\
\text { knowledge and management capacity of } \\
\text { supply chain actors and lack of access to } \\
\text { markets) }\end{array}$ \\
\hline HLPE, 2014 & $\begin{array}{l}\text { The food appropriate for human } \\
\text { consumption, being discarded or left } \\
\text { to spoil at the consumer level, } \\
\text { regardless of the cause }\end{array}$ & $\begin{array}{l}\text { HPLE, } \\
2014\end{array}$ & $\begin{array}{l}\text { A decrease, at all stages of the food } \\
\text { chain prior to the consumer level, in } \\
\text { mass, of food that was originally } \\
\text { intended for human consumption, } \\
\text { regardless of the cause }\end{array}$ \\
\hline FAO, 2014 & $\begin{array}{l}\text { A subset of food loss and represents } \\
\text { the amount of food, still suitable for } \\
\text { consumption, but gets out of the } \\
\text { supply chain for different reasons. }\end{array}$ & FAO, 2014 & $\begin{array}{l}\text { The amount of food, which is produced } \\
\text { for consumption, but gets out of the } \\
\text { supply chain for different reasons }\end{array}$ \\
\hline
\end{tabular}

Resource: Compiled by authors

The definitions in Table 1 suggest some inferences about FL and FW:

i. The upstream supply chain is mostly affected by infrastructure-related problems (inadequate technologies, poor network conditions, lack of infrastructure, etc.) and technological problems.

ii. The downstream supply chain is mostly affected by inappropriate human behavior and decisions.

Moreover, Alamar et al. (2018) and Gustavsson et al. (2011) stated that FL occurs at upstream of the supply chain which are production, harvesting, processing, transportation, storing, distributing, and retailing stages while FW occurs more frequently downstream of the supply chain, catering and household stage (Porpino et al., 2015).

Thus far, a few studies have been conducted to determine FL drivers in a different context. Chauhan et al. (2018) conducted a study to identify and model the drivers of agri-food waste management in India. Redlingshöfer et al. (2017) aimed to measure food loss at the upstream stages of the FSC in industrialized countries. Teller et al. (2018) aimed to identify the root causes of food loss occurs in a retail store. Lebersorger and Schneider (2014) quantified food loss rates in Austria retail outlets. Willersinn et al. (2015) investigate each stage of the potato supply chain to quantify food losses. 
However, Stenmarck et al. (2016) stated that food loss at the upstream stages of FSC is particularly under-researched. Moreover, Monier et al. (2010) emphasized that FL at the upstream stages are either over-emphasized as an issue or ignored at all. Although some studies revealed the drivers of FL, none of the studies gathered all FL drivers that found for the upstream stages of FSC. Thus, this paper aims to gather and synthesis all FL drivers that are found. For this purpose, we conducted a systematic literature review on empirical studies that identified FL drivers at the upstream stages of FSC. The paper is structured as follows: Section 2 describes the method and data used in this study, which protocol is applied, what are the exclusion and inclusion criteria. Section 3 presents the results of a systematic literature review. Conclusions are presented in Section 4.

\section{Methodology}

In this study, we adopted systematic literature review approach. We followed Petticrew and Roberts (2008) approach for the search of data. Besides for synthesis and conceptualization of data and for the qualitative content analysis, we followed Hsieh and Shannon (2005) approach. Three databases were used during the article selection process, which are Scopus, ScienceDirect and Web of Science. The search strategy was based on the keyword search. The following keywords searched "food waste", "food loss", "and "driver", "cause", "reason". During the search Boolean operator "AND" used. To maximize the relevant publications, we searched for the all keywords with different combinations in each databases. The research was carried out between June and September 2018.

We have identified some criteria for the inclusion of an article in the literature review. Only English-written articles, peer-reviewed articles and articles that examine food loss and food waste drivers via empirical studies are added to literature review. After finishing keyword search, we gathered 654 articles from three databases (Scopus - 528 articles; ScienceDirect 106 articles; Web of Science - 20 articles). In the second step, we scanned for duplications and we identified 279 articles that overlapped. At the third step, we examined titles and abstracts for 375 articles, and we excluded 306 irrelevant articles. As a result, we got 69 articles to full-text examination. After examining 69 articles, we identified that only 20 of them focus on the production, processing and distribution \& retailing stages of the FSC. Figure 1 illustrates the research protocol. 


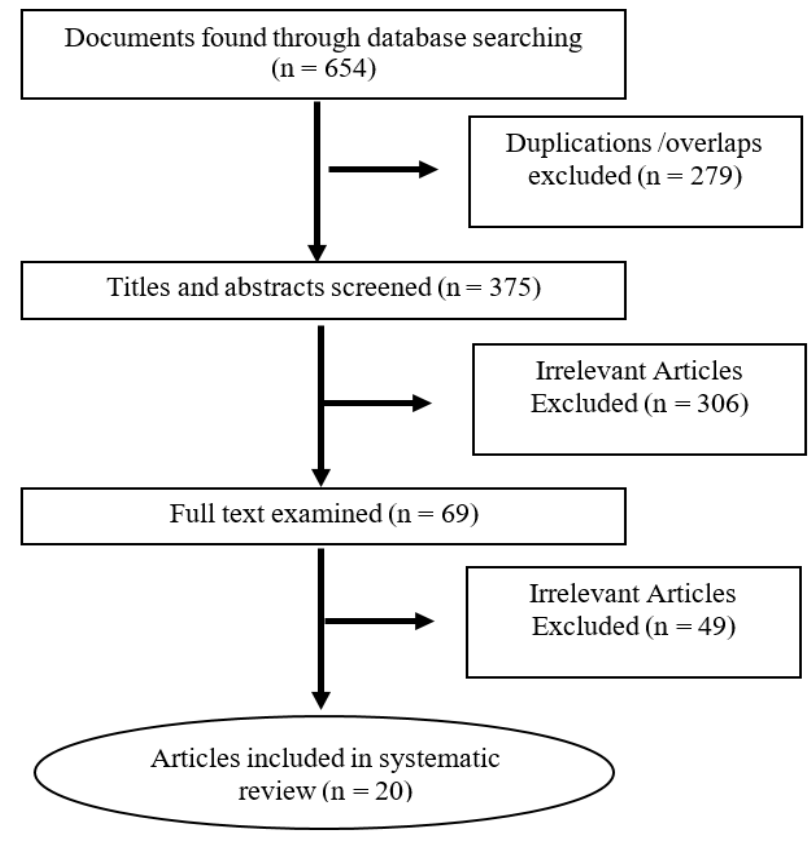

Figure 1. Research protocol

Resource: Compiled by authors

\section{Results and Discussion}

The results show that there is a growing tendency in studies about food loss drivers. Although the literature review was not limited to time, the oldest study belonged to 2011. An increase has been observed in studies conducted since 2014 (Figure 2).

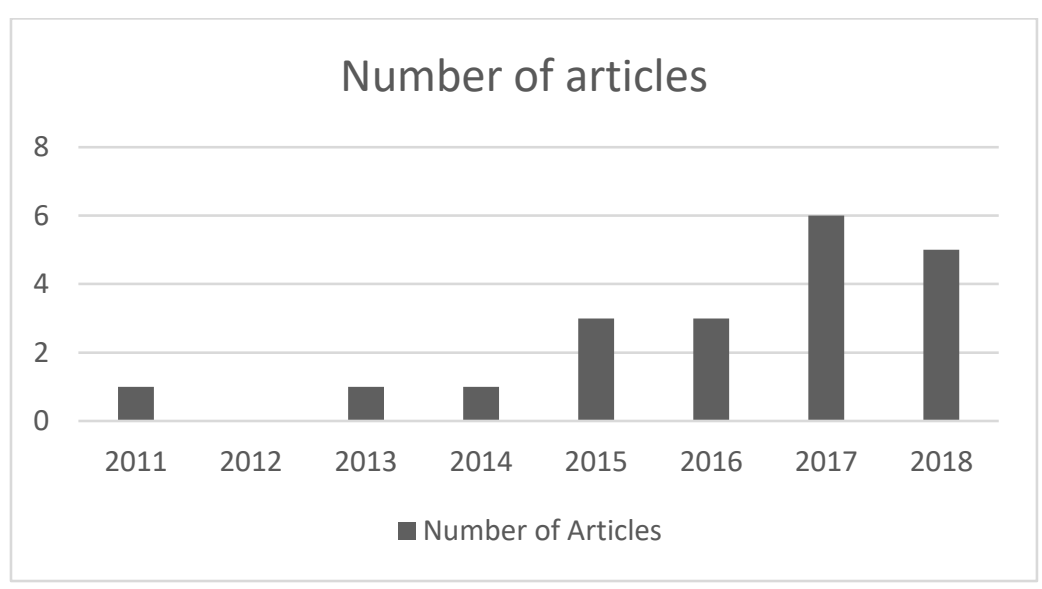

Figure 2. Distribution of articles per year

Resource: Compiled by authors

Sixty-five percent of the articles have been published in four journals. Four of the articles were published in Resources, Conservation and Recycling, and four others were published in Waste Management. Sustainability (three) and the Journal of Cleaner Production (two) were the other commonly journals that published related articles. The rest of the articles (seven) published in different academic journals. Table 2 shows the distribution of papers based on journals. 
Table 2. Distribution of papers based on journals

\begin{tabular}{lr}
\hline Name of the Journal & $\begin{array}{l}\text { No. of articles } \\
\text { published }\end{array}$ \\
\hline Resources, Conservation and Recycling & 4 \\
Waste Management & 4 \\
Sustainability & 3 \\
Journal of Cleaner Production & 2 \\
Benchmarking: An International Journal & 1 \\
International Food Research Journal & 1 \\
International Journal of Production Economics & 1 \\
International Journal of Vegetable Science & 1 \\
Journal of Environmental Research Engineering and Management & 1 \\
Journal of Extension & 1 \\
Postharvest Biology and Technology & 1 \\
Total & 20 \\
\hline Resource: Compiled by authors &
\end{tabular}

When the countries in which the studies were conducted were examined, we identified with five studies European Union member countries are the first rank. India is the second rank with three studies. Table 3 shows the countries of the papers selected.

Table 3. Distribution of papers per country

\begin{tabular}{lr}
\hline Name of the country that article conducted & No. of articles published \\
\hline European Union Countries & 5 \\
India & 3 \\
Germany & 2 \\
Kenya & 2 \\
Austria & 1 \\
France & 1 \\
Lithuania & 1 \\
Netherland & 1 \\
Scotland & 1 \\
Sweden & 1 \\
Switzerland & 1 \\
USA & 1 \\
Total & 20 \\
\hline rce: Compiled by authors
\end{tabular}

Resource: Compiled by authors

We coded each article to define FL drivers for the production, processing, and distribution \& retail stage of the FSC. We grouped the drivers considering in which part of the FSC they occurred. Thus, Figure 3 shows the main FL drivers for the production stage, processing stage and distribution \& retail stage of the FSC. 


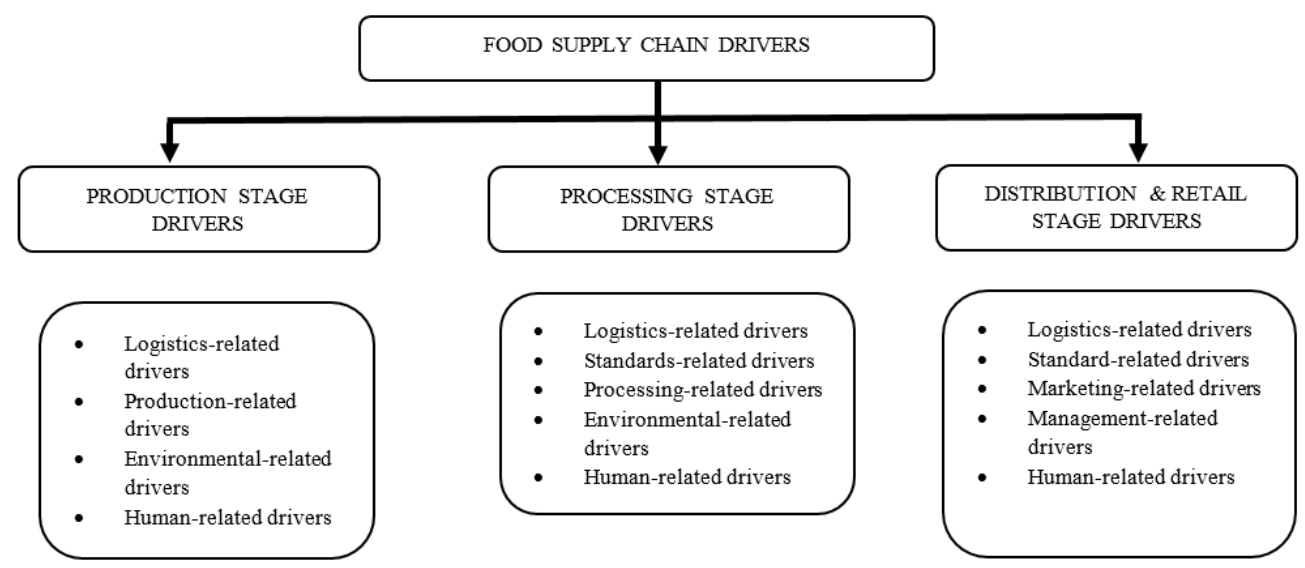

Figure 3. Food loss drivers

Resource: Compiled by authors

In the following section, each driver (factors) that causes FL at each stage and the sub-factors that form the driver are examined.

\subsection{Production Stage Drivers}

We grouped production-related FL drivers under four groups: logistics-related drivers, production-related drivers, environment-related drivers and human-related drivers. Figure 4 shows the production stage of FL drivers and sub-factors.

Transportation problems, mismanaging the demand, and wrong warehousing applications are the sub-factors of the logistics related FL drivers at the production stage of the FSC. Chauhan et al. (2018) mentioned that high transportation costs and weak transportation networks cause FL. If the transportation costs are higher than the sales price of the product, the producer will prefer to leave the product in the field, instead of selling and left food turns into waste. Weak transportation networks also lead to FL due to delays in the delivery of the product. Damage to the product during transportation causes abnormalities in the appearance of the product (Gustavsson et al., 2011). In this case, customers do not prefer to buy damaged products. Therefore, damages occurred during transportation cause FL (Canali et al., 2017; Beretta et al., 2013). Freshly harvested products should be delivered to the consumers as soon as possible. Delays in transportation can reduce the life of the products. Since consumers do not prefer shortened shelf-life products, delayed products turn into waste (Göbel et al., 2015). Wrong demand forecasting results in either in food shortage or food surplus. In food surplus case, the extra products cannot be produced on time and turns into waste (Campbell and Munden-Dixon, 2018; Chauhan et al., 2018; Beausang et al., 2017; Canali et al., 2017; Gogo et al., 2017; Redlingshöfer et al., 2017; Priefer et al., 2016; Beretta et al., 2013). Producers can make wrong forecasting due to various reasons such as supply agreements with retail chains, government subsidiaries, and lack of information dissemination within the supply chain. Storing products in a storage unit considering their properties after harvesting is essential to keep the products fresh. Thus, as many authors have found in their studies having lack of storage infrastructure give rise to FL (Chauhan et al., 2018; Gogo et al., 2018; Canali et al., 2017; Gogo et al., 2017; Willersinn et al., 2015; Beretta et al., 2013). 


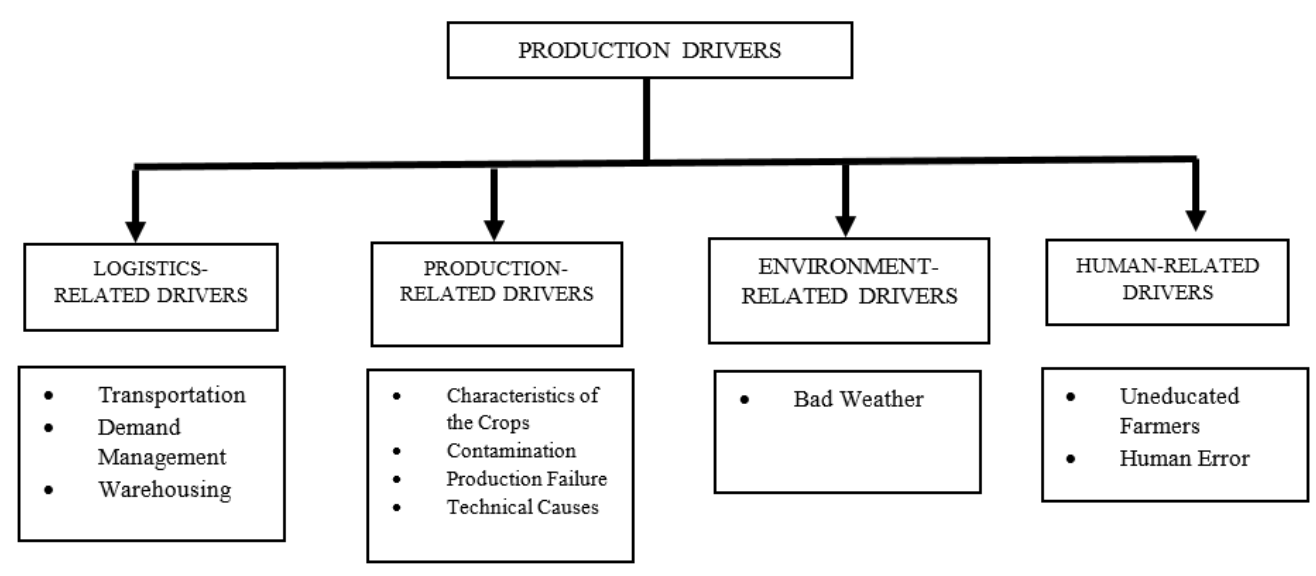

Figure 4. Food Loss Drivers at the Production Stage

Resource: Compiled by author

Characteristics of the crops, contamination, technical problems, and production failure are the sub-factors of the production-related FL drivers. Redlingshöfer et al. (2017) and Canali et al. (2017) mentioned that nature of the crops such as heterogeneity of the crop, pods being too near the soil, perishability of food staples is one the driver. Contamination is a sub-factor that leads to FL at the production stage (Campbell and Munden-Dixon, 2018; Beausang et al., 2017; Canali et al., 2017; Gogo et al., 2017; Redlingshöfer et al., 2017; Balaji and Arshinder, 2016; Priefer et al., 2016; Beretta et al., 2013). Researches revealed that the consumers would not prefer the contaminated products or products that have a risk of contamination. Another sub-factor of FL is technical causes such as inadequate systems of control (Canali et al., 2017), suboptimal operation and ease of use equipment (Canali et al., 2017), changes in production line and method of processing (Beretta et al., 2013), deficiencies through cleaning machines (Göbel et al., 2015), inefficient operations management (Priefer et al., 2016). These causes lead to the production of abnormal products, consumers will not prefer to buy such products, and eventually, food turns into waste (Gogo et al., 2018; Beausang et al., 2017; Gogo et al., 2017; Willersinn et al., 2015). Failures during the production is another sun-criterion for FL. Especially producing food off the standards is a remarkable failure (Priefer et al., 2016; Redlingshöfer et al., 2017; Chauhan et al., 2018; Canali et al. 2017; Beretta et al., 2013).

The literature review revealed that human-related drivers also cause FL at the production stage. Uneducated farmers and human error are the main sub-factors. Uneducated farmers are one of the sub-factor for food loss at the production stage (Chauhan et al., 2018). Farmers who do not know how to harvest correctly or irrigate incorrectly cause food loss. According to Campbell and Munden-Dixon (2015) and Göbel et al. (2015), human error is one of the most common reasons for food loss in all product groups. Human errors, such as using wrong fertilization methods, can lead to decrease yield or lead to food loss ultimately.

Climate change is a vital sub-factor that consists of environment-related drivers. Foul weather conditions affect the unharvested crops. Crops affected by foul weather either cannot be harvested or remain in the farmer after harvest because they do not grow as desired (Campbell and Munden-Dixon, 2018; Beausang et al., 2017; Canali et al., 2017; Gogo et al., 2017; Redlingshöfer et al., 2017; Beretta et al., 2013). 


\subsection{Processing Stage Drivers}

Considering the literature review, we grouped processing-related drivers under five groups: logistics-related drivers, processing-related drivers, quality-related drivers, environment-related drivers, and human-related drivers. Figure 5 shows the processing-related FL drivers and subfactors that form each driver.

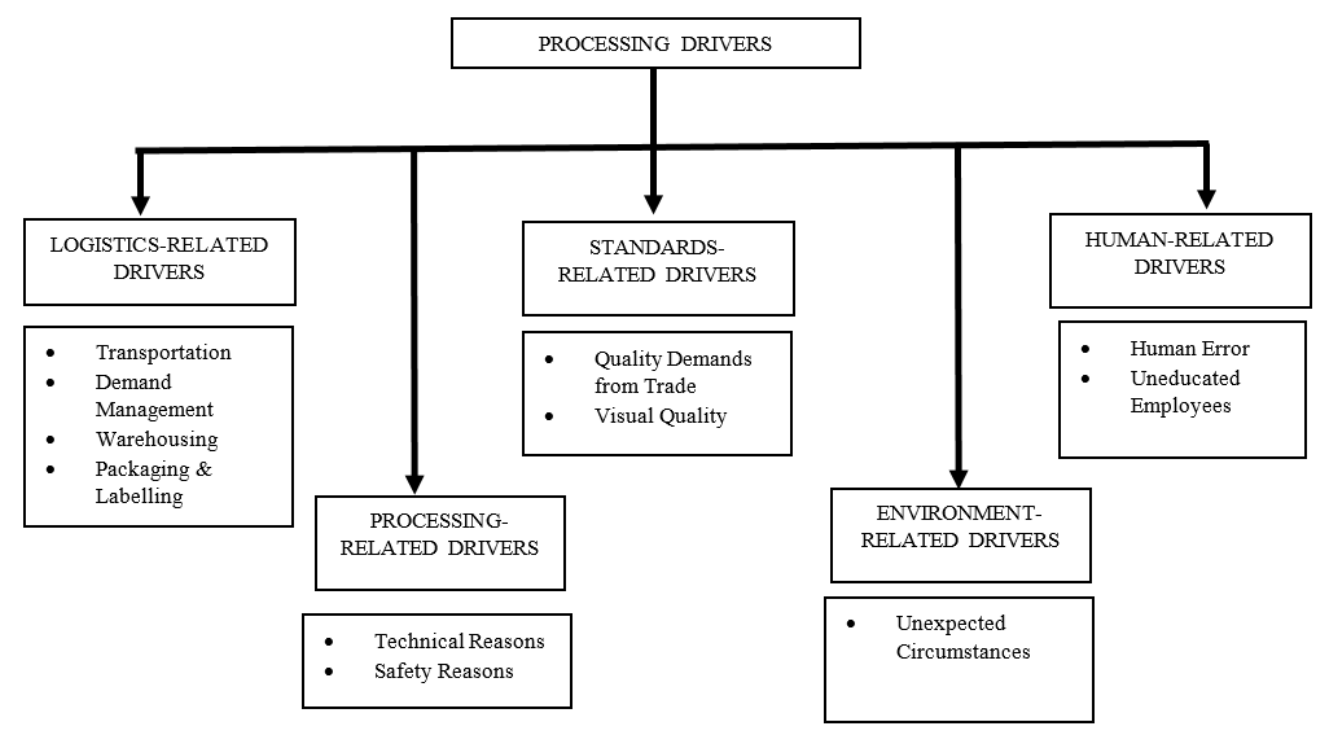

Figure 5. Food Loss Drivers at the Manufacturing Stage

Resource: Compiled by authors

Demand management, warehousing, transportation, and packaging are the main sub-factor that consist of logistics-related drivers, according to literature. Logistics-related drivers are transportation problems, mismanaging the demand, wrong warehousing application, and wrong packaging \& labeling applications. If a product needs to move in the cold chain, it means that the product will deteriorate over a specific temperature. If the deficiency is experienced in the cold chain during transportation, this means that the transported product is broken or the shelf life will be much shorter than it should. Thus, cold chain inefficiency causes food loss at the production stage (Gogo et al., 2018; Arivazhagan et al., 2017; Canali et al., 2017; Gogo et al., 2017). As Göbel et al. (2015) mentioned, delays in transportation could cause to food loss. Inaccurate demand forecasting may result in overproduction. In this case, overproduced foods cannot be consumed in time and become food loss (Raak et al., 2017). Storage conditions of raw materials, semi-finished or finished products are one of the conditions that determine the shelf life of the product.

Incorrect stacking such as wrong temperature or atmospheric condition during the storage may cause products to deteriorate while products are waiting on the shelf or shorter shelf life than expected which leads to FL (Gogo et al., 2018; Arivazhagan et al., 2017; Raak et al., 2017). Suboptimal use of packaging is one of the reasons for food loss at the manufacturing stage. Packaging defects and errors can cause food spoilage (Arivazhagan et al., 2017; Gogo et al., 2017; Raak et al., 2017; Balaji and Arshinder, 2016; Priefer et al., 2016). Besides, the products may not be able to sell because of the wrong labeling (Raak et al., 2017).

Systematic literature review revealed that processing-related drivers also cause food loss at the processing stage. Technical reasons and safety reasons are the sub-factors that constitute processing-related food loss drivers. 
Technical reasons such as residues or cleaning losses cause to food loss. Technical reasons that happen in the production line causes food loss. During the process of production, residues can appear. These residues are considered as food loss (Raak et al., 2017). In a production line, because of safety reasons, food loss can occur. During the processing stage, firms must continuously test their products due to safety concerns. These samples, taken during regular tests, are considered as an FL (Raak et al., 2017).

Literature review shows that there is a strict quality requirement about food size, shape, nutritional value, and appearance (Arivazhagan et al., 2017; Canali et al., 2017; Raak et al., 2017). Those requirements can come from both big retailers as visual quality requirements (Raak et al., 2017) and the importing countries as trade requirements (Raak et al., 2017). Developed countries implement strict requirements for developing countries about foodimporting (Raak et al., 2017). Products that do not meet the requirements cannot enter the country. Moreover, since customers do not prefer to buy odd-shaped foods, manufacturers are facing with exact requirements about food appearance (Raak et al., 2017). Generally, the product that cannot be sold because of not meeting the requirements is considered as FL since they cannot be consumed (Arivazhagan et al., 2017; Raak et al., 2017; Willersinn et al., 2015).

Environment-related drivers are another important FL driver at the processing stage. The unexpected circumstance is the only sub-criterion that forms environment-related drivers. During food production, foods are manufactured considering the protective atmosphere, contamination, and food spoilage. Thus, timing becomes vital during the manufacturing process because it is expected that the production and packaging process will be completed in a short time, considering the above issues. However, when the blackout (Raak et al., 2017) or the equipment defects occurred (Raak et al., 2017), the production line will slow down or stop. In this situation, foods can be contaminated, which leads to food loss because the foods cannot be consumed anymore.

Human-related drivers are another sub-factor that give rise to $\mathrm{FL}$ at the processing stage (Raak et al., 2017; Göbel et al., 2015). The mistakes made by the employees during the production will cause production disruption, and this will lead to food loss (Arivazhagan et al., 2017; Raak et al., 2017. The products should be produced, packaged, and transported following product requirements especially in product groups requiring special attention.

For example, cold chain products must be produced, packaged and distrusted at a specific temperature. However, an employee who has not received sufficient training can break the chain and in this case, product deterioration occurs. Since deteriorated products cannot be consumed, they turn to food loss (Göbel et al., 2015).

\subsection{Distribution \& Retailing-Related Drivers}

According to the literature review, distribution \& retailing FL drivers can be grouped under five groups; logistics-related drivers, marketing-related drivers, standards-related drivers, management-related drivers and human-related drivers. Figure 6 shows the distribution \& retailing stage FL drivers, and sub-factors that constitutes each driver.

Wrong transportation applications induce FL at the distribution \& retailing stage. Improper transportation conditions cause deterioration of products. Canali et al. (2017) and Balaji and Arshinder (2016) stated that overfilling of food containers could cause FL because overfilled fruits and vegetables can be bruised, crushed, and smashed. 
In this case, the consumer will not prefer to buy these products since the appearance of them becomes irregular, and the unsold products become FL. Göbel et al. (2015) mentioned that delays in transportation are also a reason for FL at the distribution \& retailing stage. Freshly harvested products should be delivered to the consumers immediately. However, delays during transportation will reduce the longevity of the harvested products, and since the consumers do not prefer the shortened shelf-life products, they turn into waste. If the deficiency is experienced in the cold chain during transportation, this means that the transported product is broken or the shelf life will be much shorter than it should. Thus, cold chain inefficiency causes food loss at the distribution \& retailing stage (Gogo et al., 2017; Balaji and Arshinder, 2016; Priefer et al., 2016; Mena et al., 2011). If the demand is not adequately managed at the FSC, then FL occurs. Demand fluctuates due to various reasons such as weather, market campaigns, seasonality, product launches, promotions, and special occasions. However, volatile demand makes forecasting more challenging (Canali et al., 2017) and this can cause incorrect forecasts. If more products are supplied due to incorrect forecasting, food waste occurs due to the imbalance of supply-demand (Teller et al., 2018; Canali et al., 2017; Gogo et al., 2017; Balaji and Arshinder, 2016; Mena et al., 2011).

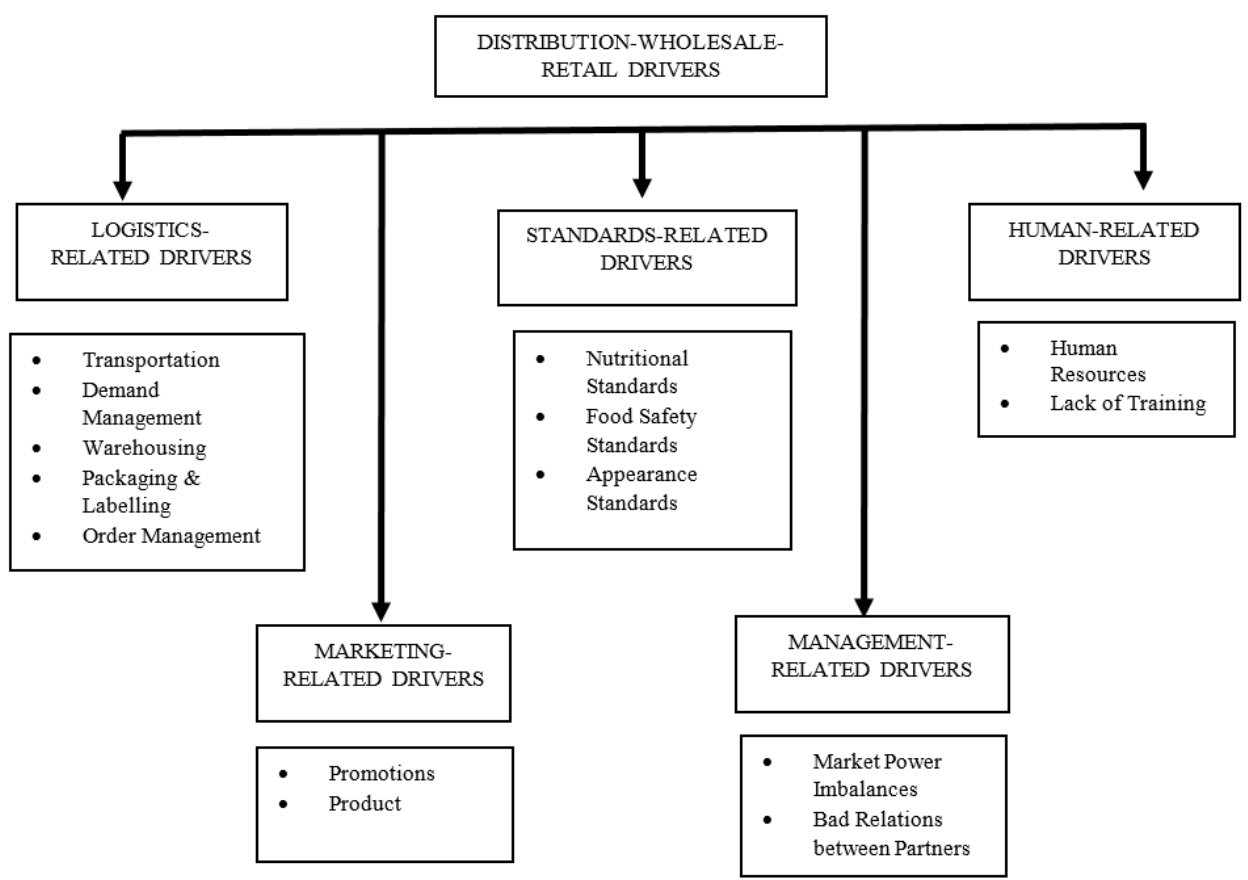

Figure 6. Food Loss Drivers at the Distribution and Retailing Stage

Resource: Compiled by authors

Wrong warehousing applications, inaccurate demand management, wrong applications in packaging and labeling, order mismanagement, and transportation problems are the sub-factors that consist of the logistics-related drivers at the distribution \& retailing stage. Inaccurate storage induces food loss (Canali et al., 2017; Gogo et al., 2017; Balaji and Arshinder, 2016; Willersinn et al., 2015; Beretta et al., 2013). Products that need to be stored under specific room temperature and atmospheric conditions will be damaged if they are stored without considering these features. In this case, products become waste. Incorrect inventory turnover calculations can end up with ordering too many food products while there is no such demand. Unsold products are stored as overstocking. 
However, these products will not be consumed since they remain in the warehouse longer than the expected time. Thus, remained products turn into waste (Canali et al., 2017; Priefer et al., 2016; Lebersorger and Schneider, 2014). Packaging and labeling related problems are another vital sub-factor that induce FL at the distribution \& retailing stage. Inappropriate packaging size is one of the drivers of FL (Teller et al., 2018; Canali et al., 2017; Aschemann-Witzel et al., 2015; Lebersorger and Schneider, 2014; Mena et al., 2011). Consumers may not be able to finish products sold in large packages at a time. Likewise, consumers may not find enough to consume a small package and may need to open the second package. Since most of the time, the consumer cannot finish the second package, then the leftovers become food waste. The consumer does not prefer to buy damaged packages. There are two main reasons for this. First, consumers do not want to buy a non-standard product at the same price. Second, consumers think that the product will be damaged/contaminated due to the damaged packaging.

For this reason, damaged packaging products cannot be sold, resulting in food waste (Gogo et al., 2018; Kliaugaite \& Kruopine, 2018; Canali et al., 2017; Gogo et al., 2017; Balaji and Arshinder, 2016; Priefer et al., 2016; Willersinn et al., 2015; Lebersorger and Schneider, 2014; Mena et al., 2011). According to Canali et al. (2017), packaging renewals can cause food waste. Because of marketing campaigns, retailers can repackage the products. This packaging may be in the form of multiple packaging of the same product or packaging of different food products together. However, in this case, the consumer who does not want to buy additional products or get unnecessary products will not prefer the re-packaged products and this can lead to food waste. Order management is a sub-factor that leads to FL. Poor ordering applications is one of the reasons for food loss (Priefer et al., 2016; Lebersorger and Schneider, 2014; Mena et al., 2011). Either the products that consumers do not demand can be delivered or products will be delivered in large quantities, due to the poor ordering applications, and the unsold products become lost.

Systematic literature review revealed that marketing-related drivers are other FL drivers at the distribution \& retailing stage. Wholesalers and retailers' marketing decisions affect the amount of wasted foods. Promotion-related drivers and product-related drivers are the sub-factor that constitutes marketing-related FL drivers. Studies showed that applied promotions could be a source of waste (Canali et al., 2017; Priefer et al., 2016; Mena et al., 2011). Stores try to finish their products by using different types of campaigns such as "buy one get one free" (BOGOF) promotions, flash sales or coupons (Priefer et al., 2016). However, this situation will unbalance the demand and lead to the destabilization of the market (Canali et al., 2017). Therefore, the producer will continue to produce more by assuming that high demand will continue in the future. However, since this high demand is temporary and the surplus production will not be consumed on time, food loss will occur (Canali et al., 2017; Priefer et al., 2016; Mena et al., 2011). Product-related drivers are the other sub-factor that induce FL at the distribution \& retailing stage. Shelf life is a significant criterion during the buying process because when a product's shelf life is close to expiring, the customer will not want to buy that product because of the safety concerns. Thus, when a product's expiry date is close or already expired, the customer does not buy that product and eventually, that product becomes waste (Kliaugaite and Kruopine, 2018; Teller et al., 2018; Canali et al., 2017; Lebersorger and Schneider, 2014). Customers can require a different type of food products according to their characteristics in a store. This situation increases the variety of products very much. Moreover, the variety is not always enough for customers. 
Customers want to find products at any time in the store, meaning that all types of food products must be available at all times in stores. Since the demand is different for each type of food product and customers want all food products at all-time in store, if the consumer does not purchase the product, it will expire on shelf and eventually become food waste (Teller et al., 2018; Tromp et al., 2015; Göbel et al., 2015). Big retailers sell most of the food types with their brands besides other brands. However, big food brands produce these products on behalf of retailers with retailers' brand packaging and labeling.

When the retailer cannot sell its own branded products, retailer branded products become food waste because those products cannot be sold anywhere else.

Wholesalers and retailers put strict rules to producers and processors about the standards of the food (Canali et al., 2017). However, these standards affect the amount of wasted food. Considering the literature review, we formed the standards-related FL drivers with the following sub-factors: nutritional standards, food safety standards, and appearance standards. According to Aschemann-Witzel et al. (2015), standard nutritional requirements is a driver that causes FL. Food demands with different nutritional values require the presence of a large number of different products in the store. This situation can lead to over-stocking of products, which have volatile demands, and becomes food loss if not consumed on time. Food safety standards are other sub-factor that leads to FL. Almost all of the wholesaler and retailers apply safety standards on products, which they sell at the store. If a product fails on the complying minimum safety standards, it cannot be sold in the store. Eventually, it becomes a food loss (Canali et al., 2017; Priefer et al., 2016). For allergic reasons, the customer may want to have different products in the store. Thus, stores have to keep the stock of many different kinds of products. Keeping the stock of these products, which have volatile demand, leads to food loss from time to time (Aschemann-Witzel et al., 2015). Many studies have shown that appearance is a significant cause of food loss. Appearance standards come from not only the wholesaler retailer firms but also the customers. The parent companies have sanction power on the branches about high appearance standards (Teller et al., 2018; Canali et al., 2017). The branches must follow the appearance requirements imposed by the parent companies. Branches have strict rules in the appearance of products such as shape, size, color and smell. Products that do not comply with these rules are not accepted to the store and often become food loss (Gogo et al., 2018; Kliaugaite \& Kruopine, 2018; Teller et al., 2018; Gogo et al., 2017; Tromp et al., 2016; Aschemann-Witzel et al., 2015; Göbel et al., 2015; Willersinn et al., 2015; Lebersorger and Schneider, 2014; Beretta et al., 2013).

The systematic literature review showed that management-related drivers also induce FL at the distribution \& retailing stage. Market power imbalances and bad retaliations between partners are the sub-factors. Since big wholesaler and retailers have the bargaining power, generally they tend to give the risk of unsold products and related costs of disposal or return the unsold or damaged products free or cancel the orders at the last minute (Barilla Center for Food and Nutrition, 2012; Stenmarck et al., 2011; Bio Intelligence Service, 2010). This situation does not help to improve relations within the supply chain because the partners who have the market power do not feel to order accurately and manage stock and this leads to an increase in weaker supply chain partner's food waste (Canali et al., 2017). Moreover, not having good relations with partners is another reason for food waste. Kliaugaite and Kruopine (2018) mentioned that having wrong attitudes about problems could cause food waste. 
When the firms do not cooperate and share accurate information within the partners of the FSC, orders will mislead the suppliers. For example, a retailer can make a promotion about a particular food product and for that, reason orders more than usual the retailer does.

If the retailer does not inform the supplier about this promotion, the supplier will assume that the new demand is continuous from now on and re-arrange its production according to this demand. However, as this demand is only for once, the surplus becomes food waste. Thus, lack of cooperation and information-sharing causes food waste at the distribution, wholesale and retail stage (Kliaugaite and Kruopine, 2018; Canali et al., 2017; Mena et al., 2011).

Human-related drivers is another FL driver at the distribution \& retailing stage. Problems based on human resources are one of the sub-factor of human-related FL drivers (Göbel et al., 2015). Human errors are one of the reasons for food loss (Göbel et al., 2015). According to Teller et al. (2018), low motivation of the employees, insufficient number of employees, lack of experience and insufficient leadership and commitment are the human resource-related drivers. All of these items are substances that will cause employees to make mistakes in food ordering, shipment and placement and therefore food loss. Lack of training is another sub-factor that constitute human-related drivers (Mena et al., 2011). In particular, warehouse employees' lack of training in storage can cause food loss. Because if the employee uses the wrong method to manage the firm's storage -FIFO/FILO-, products' expiration dates will pass while they are still waiting in the warehouse or will shorten the shelf life of the products. This situation causes the customer not to choose the product.

\section{Conclusion}

The purpose of this article is to gather and synthesis FL drivers, which are defined by empirical studies. Thus, we adopted the systematic literature review. For this purpose, we examined and extracted data from 20 studies, which are published between 2011 and 2018. As a result of the systematic literature review, we ascertain the following outcomes. First, logistics-related drivers, human-related drivers, and environment-related drivers are seen at each stage of the upstream FSC. For logistics-related drivers, we realized that bad transportation applications, mismanagement of the demand, incorrect warehousing implementations are seen as a subcriteria that causes food loss at the upstream stages of FSC. Since human is involved in each stage of the FSC, it is expected to see human-related drivers in upstream stages of the FSC. Uneducated employees and lack of skilled labors are the main factors that affect the wasted amount of food. We realized that environmental factors such as adverse weather conditions in the production stage and unexpected circumstances in the processing stage cause FL. Second, due to the nature of activities, in both production and processing stages, we identified production-related and processing-related drivers. Third, we detected that standards-related drivers are a significant driver that affects both processors and retailers. Because both retailers and consumers have strict rules about foods' appearances and not willing to buy any products that are not in regular shape.

We have some limitations. First, we conducted a literature review with only three databases. Second, we only added English-written peer-reviewed articles. Thus, we did not add the book chapters and review articles. 
Third, we tried to add all keyword during the searching process; yet there is a possibility that some articles can be excluded from the literature review because of using different terminologies.

\section{References}

Alamar, M.D.C., Falagán, N., Aktas, E., \& Terry, L.A. (2018). Minimizing food waste: A call for multidisciplinary research. Journal of the Science of Food and Agriculture, 98 (1), 1-4. doi: $10.1002 /$ jsfa. 8708

Arivazhagan, R., Geetha, P., \& Ravilochanan, P. (2017). Assessment of wastage in fruit supply chain with respect to fruit processing units in Tamilnadu, India. International Food Research Journal, 23(2), 723-732.

Aschemann-Witzel, J., de Hooge, I., Amani, P., Bech-Larsen, T., \& Oostindjer, M. (2015). Consumer-related food waste: Causes and potential for action. Sustainability, 7, 64576477. https://doi.org/10.3390/su7066457

Barilla Center for Food \& Nutrition. (2012). Eating Planet 2012. http://www.worldwatch.org/system/files/KCTV\%20042012.pdf

Beausang, C., Hall, C., \& Toma, L. (2017). Food waste and losses in primary production: Qualitative insights from horticulture. Resources, Conservation \& Recycling, 126, 177 185. https://doi.org/10.1016/j.resconrec.2017.07.042

Beretta, C., Stoessel, F., Baier, U., \& Hellweg, S. (2013). Quantifying food losses and the potential for reduction in Switzerland. Waste Management, 33, 764-773. https://doi.org/10.1016/j.wasman.2012.11.007

Bio Intelligence Service. (2010). Preparatory study on food waste across EU 27. http://ec.europa.eu/environment/eussd/pdf/bio_foodwaste_report.pdf

Busetti, S. (2019). A theory-based evaluation of food waste policy: evidence from Italy. Food Policy. 101749. https://doi.org/10.1016/j.foodpol.2019.101749

Buzby, J.C., \& Hyman, J. (2012). Total and per capita value of food loss in the United States. Food Policy, 37, 561-570. https://doi.org/10.1016/j.foodpol.2012.06.002

Campbell, D., \& Munden-Dixon, K. (2018). On-farm food loss: Farmers perspectives on food waste. Journal of Extension, 56(3), 1-9.

Canali, M., Amani, P., Aramyan, L., Gheoldus, M., Moates, G., Östergren, K., Silvennoinen, K., Waldron, K., \&Vittuari, M. (2017). Food waste drivers in Europe, from identification to possible interventions. Sustainability, $9, \quad 37-70$. https://doi.org/10.3390/su9010037

Chauhan, A., Debnath, R.M., \& Singh, S.P. (2018). Modelling the drivers for sustainable agrifood waste management. Benchmarking: An International Journal, 25(3), 981-993. https://doi.org/10.1108/BIJ-07-2017-0196

FAO (Food and Agriculture Organization of the United Nations). (1981). Food loss prevention in perishable crops. http://www.fao.org/3/s8620e/s8620e00.htm

FAO. (2013). Food wastage footprint: Impacts on natural resources (Summary Report). http://www.fao.org/3/i3347e/i3347e.pdf

FAO. (2014). Regional conference for near East, thirty-second session. http://www.fao.org/3/mj407E/mj407E.pdf

FAO. (2018). The State of food security and nutrition in the world. http://www.fao.org/3/I9553EN/i9553en.pdf

Gjerris, M., \& Gaiani, S. (2013). Household food waste in Nordic countries: Estimations and ethical https://www.ntnu.no/ojs/index.php/etikk_i_praksis/article/view/1786/1783 
Göbel, C., Langen, N., Blumenthal, A., Teitscheid, P., \& Ritter, G. (2015). Cutting food waste through cooperation along the food supply chain. Sustainability, 7, 1429-1445. https://doi.org/10.3390/su7021429

Gogo, E.O., Opiyo, A., Ulrichs, C., \& Huykens-Keil, S. (2018). Loss of African indigenous leafy vegetables along the supply chain. International Journal of Vegetable Science, 24(4), 361-382. https://doi.org/10.1080/19315260.2017.1421595

Gogo, E.O., Opiyo, A.M., Ulrichs, C., \& Huyskens-Keil, S. (2017). Nutritional and economic postharvest loss analysis of African indigenous leafy vegetables along the supply chain in Kenya. Postharvest Biology and Technology, 130, 39-47. https://doi.org/10.1016/j.postharvbio.2017.04.007

Gunders, D. (2012). Wasted: How America is losing up to 40 percent of its food from farm to fork to landfill. https://www.nrdc.org/sites/default/files/wasted-food-IP.pdf

Gustavsson, J., Cederberg, C., \& Sonesson, U. (2011). Global food losses and food waste. http://www.fao.org/3/a-i2697e.pdf

Halloran, A. Clement, J., Kornum, N., Bucatariu, C., \& Magid, J. (2014). Addressing food waste reduction in Denmark. Food Policy. 49: 249-301. https://doi.org/10.1016/j.foodpol.2014.09.005

Hanson, C., \& Mitchell, P. (2017). The business case for reducing food loss and waste. https://champions123.org/wp-content/uploads/2017/03/report_-business-case-forreducing-food-loss-and-waste.pdf

Hodges, R.J., Buzby, J.C., \& Bennett, B. (2010). Postharvest losses and waste in developed and less developed countries: Opportunities to improve resource use. The Journal of Agricultural Science. 149(S1): 37-45. doi:10.1017/S0021859610000936

HPLE. (2014). Food loss and waste in the context of sustainable food systems. http://www.fao.org/3/a-i3901e.pdf

Hsieh, H.F., \& Shannon, S.E. (2005). Three approaches to qualitative content analysis. Qualitative Health Research, 15(9), 1277-1288. DOI:10.1177/1049732305276687

Huston, T. (2017). How do we feed the planet in 2050? The Guardian Labs. https://www.theguardian.com/preparing-for-9-billion/2017/sep/13/population-feedplanet-2050-cold-chain-environment

Kliaugaite, D., \& Kruopiene, J. (2017). Food waste generation and prevention measures in the retail sector: A Comparative Study. Journal of Environmental Research, Engineering and Management, 74(4), 7-20. DOI: 10.5755/j01.erem.73.4.19941

Kummu, M., de Moel, H., Porkka, M., Siebert, S., Varis, O., \& Ward, P.J. (2012). Lost food, wastes resources: Global food supply chain losses and their impacts on freshwater, cropland, and fertilizer use. Science of the Total Environment, 438, 477-489. https://doi.org/10.1016/j.scitotenv.2012.08.092

Lebersorger, S., \& Schneider, F. (2014). Food loss rates at the food retail, influencing factors and reasons as a basis for waste prevention measures. Waste Management, 34, 19111919. https://doi.org/10.1016/j.wasman.2014.06.013

Lipinski, B., Hanson, C., Lomax, J., Kitinoja, L., Waite, R., \& Searchinger, T. (2013). Installment 2 of "creating a sustainable food future" Reducing food loss and waste. Working paper, World Resources Institute, Washington, DC, May.

Loopstra, R., Reeves, A., \& Stuckler, D. (2016). Rising food insecurity in Europe. The Lancet, 385(9982), 2041. DOI:https://doi.org/10.1016/S0140-6736(15)600983-7

Mena, C., Adenso-Diaz, B., \& Yurt, O. (2011). The causes of food waste in the supplier-retailer interface: Evidence from the UK and Spain. Resources, Conservation and Recycling, 55, 648-658. DOI:10.1016/j.resconrec.2010.09.006

Monier, V., Shailendra, M., Escalon, V., O’Connor, C., Gibon, T., Anderson, G., Hortense, M., \& Reisinger, H. (2010). Preparatory study on food waste across EU 27. European Commission (DG ENV) Directorate C-Industry. Final report 
Parfitt, J., Bathel, M., \& Macnaughton, S. (2010). Food waste within food supply chains: quantification and potential for change to 2050. Philosophical Transactions of the Royal Society B, 365, 3065-3081. https://doi.org/10.1098/rstb.2010.0126

Petticrew, M. \& Roberts, H. (2008). Systematic reviews in the social sciences: a practical guide. Oxford, Blackwell Publishing.

Porpino, G., Wansink, B., \& Parente, J. (2016). Wasted positive intentions: The role of affection and abundance on household food waste. Journal of Food Products Marketing, 22(7), 733-751. https://doi.org/10.1080/10454446.2015.1121433

Priefer, C., Jörissen, J., \& Brautigam, K.R. (2013). Technology options for feeding 10 billion people: options for cutting food waste. http://www.europarl.europa.eu/RegData/etudes/etudes/join/2013/513515/IPOLJOIN_ET(2013)513515_EN.pdf

Priefer, C., Jörissen, J., \& Brautigam, K.R. (2016). Food waste prevention in Europe - A causedriven approach to identify the most relevant leverage points for action. Resources, $\begin{array}{llll}\text { Conservation } \quad \text { and } & \text { Recycling, } & 109 & \text { 155. }\end{array}$ https://doi.org/10.1016/j.resconrec.2016.03.004

Raak, N., Symmank, C., Zahn, S., Aschemann-Witzel, J., \& Rohm, H. (2017). Processing- and product-related causes for food waste and implications for the food supply chain. Waste Management, 61, 461-472. https://doi.org/10.1016/j.wasman.2016.12.027

Redlingshöfer, B., Coudurier, B., \& Georget, M. (2017). Quantifying food loss during primary production and processing in France. Journal of Cleaner Production, 164, 703-714. https://doi.org/10.1016/j.jclepro.2017.06.173

Stenmarck, A., Jensen, C., Quested, T., Moates, G., Buksti, M., Cseh, B., Juul, S., Parry, A., Politano, A., Redlingshofer, B., Scherhaufer, S., Silvennoinen, K., Soethoudt H., Zübert, C., \& Östergren K. (2016). Estimates of European food waste levels. FUSIONS Report. ISBN 978-91-88319-01-2.

Teller, C., Holweg, C., Reiner, G., \& Kotzab, H. (2018). Retail store operations and food waste.

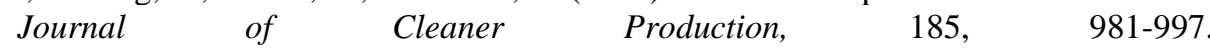
https://doi.org/10.1016/j.jclepro.2018.02.280

Teuber, R., \& Jensen, J.D. (2016). Food loss and food waste: Extent, underlying drivers and impact assessment of prevention approaches. https://staticcuris.ku.dk/portal/files/169753425/IFRO_Report_254.pdf

Tropm, S.O., Haijema, R., Rijgersberg, H., \& van der Vorst, J.G.A.J. (2016). A systematic approach to preventing chilled-food waste at the retail outlet. International Journal Production Economics. 162, 508-518. https://doi.org/10.1016/j.ijpe.2016.10.003

von Grebmer, K., Bernstein, J., Nabarro, D., Prasai, N., Amin, S., Yohannes, Y., Sonntag, A., Patterson, F., Towey, O., \& Thompson, J. (2016). The concept of the global hunger index.

http://ebrary.ifpri.org/utils/getfile/collection/p15738coll2/id/130709/filename/130920 .pdf

Willersinn, C., Mack, G., Mouron, P., Keiser, A., \& Siegrist, M. (2015). Quantity and quality of food losses along the Swiss potato supply chain: Stepwise investigation and the influence of quality standards on losses. Waste Management, 46, 120-132. https://doi.org/10.1016/j.wasman.2015.08.033 